LITERATURA 



\title{
EL FLÂNEUR Y LA FLANEUSE EN LA HISTORIA DE LA PINTURA, EL CINE, LA FOTOGRAFÍA Y LA ILUSTRACIÓN
}

\author{
Dorde Cuvardic García
}

\begin{abstract}
RESUMEN
El flâneur, como tipo social reconocible, ha sido representado, desde el siglo XIX, en la cultura visual, tanto en la pintura y la ilustración, como en el cine y la fotografía. La flanerie se desarrolla en el tiempo, por lo que en el caso de la pintura, arte del espacio, se presentan ciertas dificultades para distinguirle. Por lo general, se le identifica por la vestimenta, el gesto y el uso del espacio que adopta. Suele quedar visualmente asimilado al dandy ocioso que pasea. Por otra parte, algunos pintores han quedado identificados como flâneurs. Así, la representación de la modernidad en los pintores impresionistas se visualiza en las pinturas a partir de la utilización de un punto de vista fragmentario, aleatorio y descentrado sobre el espacio público. Por último, en los estudios cinematográficos, así como en la fotografía, la mirada de la cámara cinematográfica sobre la calle, desde Kracauer, también ha sido comprendida como flanerie. Asimismo, algunos investigadores han tratado de identificar a personajes que se desempeñen como flâneurs o flaneuses en la historia del cine.

Palabras clave: Flaneur, flaneuse, pintura, ilustración, fotografía, cine, modernidad cultural, cultura visual.
\end{abstract}

\begin{abstract}
The flâneur, as a social recognizable type, has been represented since the XIX century on visual culture (paintings, illustrations, films and photography). Flanerie is developed through time, thus in the case of painting, the art of space, there are certain difficulties to characterize it. In any case, flâneurs are generally identified by their clothing, their expressions, and the use of space they adopt. In these cases, they are often assimilated to the idle dandy taking a stroll. On the other hand, some painters have been identified as flâneurs. Moreover, the flâneur's point of view is visualized on paintings from a fragmentary, random and off-centered framing of public spaces. Finally, within the film and photography theory, the camera look over the street has also been understood as flanerie. Likewise, some researchers have tried to identify the flâneur and the flaneuse in their character roles through film history.

Key words: Flaneur, flaneuse, painting, illustration, photography, cinema, cultural modernity,
\end{abstract} visual culture.

Dr. Dorde Cuvardic García. Profesor. Escuela de Filología, Lingüística y Literatura. Universidad de Costa Rica. Correo electrónico: dcuvardic@yahoo.es

Recepción: 28- 09- 2011

Aceptación: 02- 11- 2011 
En este artículo se analiza la relación entre el flâneur, el paseante callejero urbano ocioso, y la cultura visual, específicamente la pintura, la ilustración, el cine y la fotografía ${ }^{1}$. Se vislumbran dos vías de análisis. En primer lugar, la representación visual del espacio urbano desde un punto de vista móvil en la pintura, el cine y la fotografía se puede equiparar a la mirada peripatética del flâneur. La cámara (en el caso del cine y la fotografía) o el encuadre (en el caso de la pintura y la ilustración) pueden adoptar, en la representación de la urbe, este punto de vista. Los espacios y los tipos sociales urbanos se representan como si fueran observados por una persona peripatética. En segundo lugar, se puede investigar la historia de la representación visual del flâneur o de la flaneuse como tipos sociales reconocibles en pinturas, grabados, fotografías y películas.

\section{La representación visual del espacio urbano y su homología con la mirada peripatética del flâneur}

La pertinencia de representar la modernidad urbana, es decir, el mundo de la contemporaneidad (y ya no el pasado mitológico o bíblico), ingresa al ámbito de la crítica de arte en el siglo XIX. La representación de la ciudad, según Baudelaire, debe ser emprendida por un artista que se sumerja en sus espacios públicos. Es decir, si el artista quiere representar la modernidad cultural, debe ser un flâneur. En un artículo poco conocido del Salón de 1845, titulado "Esculturas", Baudelaire (1996: 85) defiende implícitamente la presencia de lo urbano -lo nuevo- en la pintura cuando declara que 'nos' apremia y rodea el heroísmo de la vida moderna, lo nuevo, y que será el verdadero pintor el que sabrá arrancar el lado épico a esta vida, el que sabrá hacer ver y comprender al público lo grande y poético que es el individuo con corbata y botines de charol.

Este aprecio por la novedad surge en la historia de la estética con la aparición del discurso de lo pintoresco, cuyo valor es, precisamente, lo nuevo. Joseph Addison (1991), en Los placeres de la imaginación, uno de los más importantes ensayos de estética del siglo XVIII, argumenta sobre los valores de la diversidad y de la novedad:

\footnotetext{
Nos molesta vivamente estar mirando cerros y valles, donde cada cosa continúa fija y estable en el mismo lugar y postura: y al contrario nuestros pensamientos hallan agitación y alivio a la vista de aquellos objetos que están siempre en movimiento y deslizándose a los ojos del espectador. (1991: 141)
}

Este discurso de lo pintoresco, aplicado en el siglo XVIII al espacio rural humanizado (domesticado, civilizado), y que tiene la novedad de los 'objetos que siempre están en movimiento y deslizándose ante los ojos del espectador' como principal valor, encontrará su traducción en el siglo XIX en la 'pintura' de costumbres propio de las escenas urbanas: lo pintoresco rural pasa a convertirse, en el movimiento costumbrista, en pintoresco urbano. El pensamiento encuentra agitación, en este último caso, ante la transitoriedad urbana: podríamos decir también excitación o atracción. El agente encargado de representar esta transitoriedad es el artista flâneur.

En otra crítica poco conocida, también promueve la necesidad de representar el paisaje urbano. En el Salón de 1859, sección VII, "El paisaje”, Baudelaire hecha en falta "un género que llamaría con gusto el paisaje de las grandes ciudades, es decir, la colección de las grandezas y de las bellezas que resultan de una poderosa aglomeración de hombres y monumentos" (1996: 278). Del señor Merino, que años antes había pintado aguafuertes de París, declara Baudelaire, como crítico de arte, la solemnidad con la que representa una ciudad inmensa: 
La majestad de la piedra acumulada, los campanarios señalando al cielo con el dedo, los obeliscos de la industria vomitando contra el firmamento sus coaliciones de humo, los prodigiosos patíbulos de los monumentos en reparación, aplicando sobre el cuerpo sólido de la arquitectura calada una belleza tan paradójica, el cielo tumultuoso, cargado de cólera y de rencor, la profundidad de las perspectivas aumentada por el pensamiento de todos los dramas que contiene, ninguno de los elementos complejos de los que se compone el doloroso y glorioso decorado de la civilización había sido olvidado. (1996: 278)

Se trata de obtener belleza de la fealdad. En la crítica de arte de El pintor de la vida moderna, la épica de las transformaciones urbanas es valorada positivamente, al ser tema de representación pictórica, actitud muy alejada del yo-lírico melancólico y autoexiliado de Las flores del mal y de Los pequeños poemas en prosa. ¿Qué valores son pregonados? La industrialización, la acumulación de formas de pensar diferentes, la diversidad, la mezcla de lo viejo y de lo nuevo, las constantes transformaciones del paisaje urbano, la multiplicación, hasta el infinito, de sus dramas humanos...

El elogio de la novedad también queda expresado en la famosa descripción que Baudelaire nos ofrece del flâneur y de la modernidad en el ensayo "La modernidad":

\begin{abstract}
De este modo va, corre, busca. ¿Qué busca? Sin duda, este hombre, tal como lo he pintado, este solitario dotado de una imaginación activa, viajando siempre a través del gran desierto de hombres, tiene un fin más elevado que el de un simple paseante, un fin más general, otro que el placer fugitivo de la circunstancia. Busca algo que se nos permitirá llamar la modernidad; [...] Se trata, para él, de separar de la moda lo que puede contener de poético en lo histórico, de extraer lo eterno de lo transitorio [...] La modernidad es lo transitorio, lo fugitivo, lo contingente, la mitad del arte, cuya otra mitad es lo eterno y lo inmutable. (1996: 361)
\end{abstract}

Es decir, se trata de extraer la belleza (valor eterno) de lo transitorio, del espacio público de la ciudad (tipificada como desierto, metáfora común en el siglo XIX). París, en particular, como destaca Tester (1994: 16-7), es paradigma de la modernidad, al apreciar las transformaciones de la capital francesa. Lo eterno, por su parte, como señala Stierle (1980), está otorgado por la obra de arte, por la forma expresiva (en términos semióticos) resultante del proceso creativo del artista: "Lo eterno es la unidad o gestalt de una obra de arte, una unidad que, para Baudelaire, está separada de la temporalidad. Es el producto de la más profunda subjetividad del artista" (1980: 345-361). Por lo tanto, la ciudad es lo efímero, que el artista convierte en forma expresiva artística, en belleza eterna.

¿Quién se encarga de extraer lo eterno de lo transitorio? El flâneur, aunque no lo nombra con este término. En "El artista, hombre de mundo, hombre de la multitud y niño", Baudelaire lo tipifica como "Gran enamorado de la multitud y del incógnito" (1996: 355). Nos ofrece una definición del flâneur a partir de sus actividades. Al describir al Sr. G. (por lo general asociado al dibujante y pintor Constantin Guys) explica que la multitud es su dominio:

Su pasión y su profesión es adherirse a la multitud. Para el perfecto paseante, para el observador apasionado, es un inmenso goce el elegir domicilio entre el número, en lo ondeante, en el movimiento, en lo fugitivo y lo infinito. Estar fuera de casa, y sentirse, sin embargo, en casa en todas partes; ver el mundo, ser el centro del mundo y permanecer oculto al mundo [...] El observador es un príncipe que disfruta en todas partes de su incógnito. [...] el enamorado de la vida universal entra en la multitud como en un inmenso depósito de electricidad. También se le puede comparar, a él, a un espejo tan inmenso como la multitud; a un caleidoscopio dotado de consciencia, que, a cada uno de sus movimientos, representa la vida múltiple y la gracia moviente de todos los elementos de la vida. Es un yo insaciable del no yo, que a cada instante, lo restituye y lo expresa en imágenes más vivas que la vida misma, siempre inestable y fugitiva. [...] Admira la eterna belleza y la sorprendente armonía de la vida en las capitales, armonía tan providencialmente mantenida en el tumulto de la libertad humana. (Baudelaire 1996: 359) 
El artista que representa la modernidad focaliza la atención en la cotidianeidad de sus espacios públicos. No 'exhibe' ante los demás su actitud reflexiva, necesaria para su creación artística: se hace pasar por un transeúnte o consumidor más. Tiene la mirada oculta del voyeur. Mantiene su reflexividad en secreto (incógnito). Es un caleidoscopio (metáfora 'óptica' que comienza a proliferar en el siglo XIX), es decir, está abierto, potencialmente, a la representación de la diversidad y de la fragmentación de la experiencia perceptiva en la urbe, con el propósito final de obtener belleza (valor eterno). Se encuentra predispuesto a la identificación con la Otredad ('yo insaciable del no yo').

El escritor francés considera que la experiencia fragmentaria y fugaz de la urbe exige una forma que muestre este contenido. Mediante la técnica del esbozo o croquis, establece la homología entre los acontecimientos fugaces de la vida pública y su representación expresiva. El carácter temporalmente efímero de la modernidad cultural debe quedar representado, según Baudelaire, en trazos rápidos. Esta es la premisa implícita del poco conocido artículo "El croquis de costumbres", en el que "la representación de la vida burguesa y los espectáculos de moda, el medio más expeditivo y menos costoso es el mejor [...] hay en la vida trivial, en la metamorfosis cotidiana de las cosas exteriores, un movimiento rápido que impone al artista la misma velocidad de ejecución" (Baudelaire 1996: 353). Es decir, la percepción fugaz de los acontecimientos urbanos acelerados y fragmentarios por el artista flâneur se registrará de la manera más pertinente mediante el trazo rápido del croquis, modalidad expresiva que manifiesta los mismos valores semánticos. Al mismo tipo de homología llega Fritzsche (1996: 134-147) cuando compara la percepción fragmentada del observador callejero y la representación del acontecer en la prensa berlinesa alrededor de 1900.

Herbert, además, vincula la estética de la flanerie con una modalidad visual de trazo rápido: la caricatura. Precedente del pintor impresionista, el caricaturista es un flâneur que encuentra en los acontecimientos públicos temas pertinentes para la sátira: "Capturar un elusivo pero característico momento de la vida de la ciudad fue también el propósito del caricaturista [...] era, en efecto, un flâneur visual, y sus caricaturas aparecieron en los mismos periódicos que incorporaron los ensayos y los relatos del flâneur escritor" (1988: 39-40).

Asimismo, el pintor impresionista ha sido equiparado al flâneur por utilizar procedimientos pictóricos que expresaban las condiciones perceptivas de este tipo social. Meyer Schapiro ${ }^{2}$ fue uno de los primeros críticos de arte en reflexionar sobre esta homología al destacar en estos pintores

\footnotetext{
su descubrimiento de un mundo externo fenoménico constantemente cambiante, donde las formas dependían de la posición momentánea del espectador causal o en movimiento [...] Y en las nuevas técnicas impresionistas, que quiebran los objetos en puntos de color finamente discriminados, así como en la visión momentáneamente 'accidental', el impresionismo encontró [...] condiciones de sensibilidad bastante relacionadas con aquellas pertenecientes al paseante urbano y al refinado consumidor de mercancías de lujo. (Clark 1984: 3)
}

¿Qué pintores impresionistas se 'sumergieron' en la multitud, en la vida pública? Herbert (1988: 33) considera flâneurs sobre todo a Manet, Degas y Caillebote. Degas, en particular, tuvo como lema Ambulare, postea laborare (Forgione 2005: 670), es decir, Caminar, después trabajar. Por su parte, Reff (1988: 135-167) considera que, al hacer un estudio de los espacios exteriores, Manet se comportó como un flâneur y transmitió la inmediatez de la experiencia de este tipo social en sus pinturas. Körner, (1996), asimismo, especifica que "Manet fue el clásico flâneur, y él profesionalizó en su existencia lo que le distingue, la mirada distanciada" (1996: 40). 
Las escenas urbanas, en el Impresionismo, implican el punto de vista de un enunciador que callejea. Considera Herbert (1988: 33) que Manet, Degas y Caillebote registraron en sus pinturas urbanas el punto de vista móvil que ellos mismos experimentaron al deambular por las calles parisinas. En particular, Antonin Proust (Thomas 2006: 32), amigo de Manet, consideró Cantante callejera como ejemplo de su condición de flâneur: la mirada adoptada en este cuadro registra el encuentro casual entre esta mujer y el pintor. Herbert (1988: 36), fundamentándose en la misma fuente documental, llega a las mismas conclusiones. Por su parte, Forgione (2005: 670) considera que en Plaza de la Concordia (El Vizconde Lepic y sus hijas cruzando la Plaza de la Concordia), 1875, de Degas, el punto de vista evoca el del propio artista al caminar.

Diversos son los espacios públicos visitados por estos pintores, representados a su vez en su pintura: calles, teatros, café-concerts... Timothy C. Clark utilizó la distribución de los espacios visitados por el militar, el dandi, la mujer y la prostituta, los tipos sociales presentados por Baudelaire en El pintor de la vida moderna, a la hora de organizar, en su libro La pintura de la vida moderna, los espacios representados por los pintores impresionistas ${ }^{3}$.

Las imágenes que adoptan el punto de vista de un pintor o ilustrador flâneur sobre la ciudad también son muy comunes en la Inglaterra decimonónica. Cercana a la mirada del científico social que pretende certificar la miseria de la capital británica son las ilustraciones del francés Gustave Doré para Londres: una peregrinación (1872), de Blanchard Jerrold, obra que, en lugar de interpretar esta ciudad en términos de capital y trabajo, establece la diferenciación entre el mundo del rentista -el West End del ocio, el consumo y el espectáculoy el del delincuente empobrecido -el East End-(Walkowitz 1995: 53). Entre otros espacios callejeros, Doré ofrece escenas de los slums.

La mirada del flâneur también estructura las pinturas urbanas del Impresionismo y del Expresionismo en Alemania. Czaplicka (1991: 3-36) analiza escenas urbanas de Berlín durante los últimos años del Imperio y los primeros de la República de Weimar: ciudad típicamente industrial, la capital alemana queda representada desde tipos sociales y escenarios obreros en cuadros de Hans Baluschek, Franz Skarbina y Karl Hubbuch. Por su parte, Haxthausen (1991: 58-94) refuta las tradicionales interpretaciones de los historiadores del arte, quienes consideran la serie de cuadros sobre prostitución y espacio callejero del expresionista Ernst Ludwig Kirchner como manifestación de la corrupción y de la decadencia moral de la metrópoli berlinesa ${ }^{4}$. En el marco de la solicitación ambigua del intercambio sexual callejero, considera que estos cuadros constituyen, en el marco de las actitudes de Kirchner hacia el desnudo y la sexualidad, una descripción dionisíaca, glorificada, de la sexualidad, liberada de las restricciones morales burguesas.

En cambio, un pintor que ofrece escenas callejeras como sinécdoque de la degradación moral del capitalismo, en cuadros como Homenaje a Oskar Panizza (1917/1918) es George Grosz. Algunos de sus dibujos y pinturas representan escenas cuyas acciones degradadas y violentas se proyectan al interior de las viviendas de los edificios, espacios visibles gracias a la apertura de las ventanas (Lewis 1991: 111-140). Otro excelente ejemplo es La calle de Praga (1920), de Otto Dix, quien nos ofrece la escena del interior de un burdel, desde el punto de vista de un flâneur, en Altar para caballeros (1920).

Pollock retomó la clasificación de los espacios de la modernidad de Baudelaire, ya utilizados previamente por Clark, y se preguntó si las pintoras impresionistas también los representaron. En su libro Vision and difference. Femininity, feminism and histories of art (1988), investigó las posibilidades para que la sociedad burguesa francesa diera acceso a las pintoras impresionistas (Berthe Morisot, Mary Cassat) a la hora de emprender una flanerie urbana en las 
mismas condiciones que los pintores de este movimiento pictórico. Su conclusión es negativa: mientras estos últimos tuvieron mayor acceso y libertad de movimiento en ciertos espacios públicos, las primeras enfrentaron obstáculos. Pollock demuestra que la cultura patriarcal burguesa, en el marco de la división del espacio público entre esfera pública masculina y privada femenina, impidió a las pintoras impresionistas convertirse en flaneuses, situación que determinó la elección y la mirada hacia los espacios que representaron: mientras que las alcobas, las salas de visitas, los balcones, los teatros y los parques son espacios compartidos tanto por los pintores como por las pintoras impresionistas, los bastidores de los teatros, los cafés, los folies y los prostíbulos, en cambio, constituyeron espacios exclusivos de representación de los pintores.

\subsection{La representación visual del flâneur en pinturas y grabados}

La representación del espectador cuenta con una larga tradición en la pintura. Conocida es su incorporación en las escenas paisajísticas, tanto en la pintura prerromántica como en la romántica. También el flâneur, la figura del observador que asume una mirada reflexiva sobre los acontecimientos urbanos, cuenta con una larga tradición en la cultura visual de la modernidad.

Las dos ilustraciones que comentaré seguidamente fueron publicadas con una distancia temporal de siglo y medio, pero el asunto es el mismo: en ambas, el flâneur escritor toma apuntes de sus observaciones en los espacios públicos de la ciudad. En el primer caso, en imagen de George Cruikshank para la escena Streets-Morning (Calles-Mañana), de la primera compilación ilustrada de las producciones periodísticas de Charles Dickens, Sketches by Boz (1839) el flâneur observa la actividad de una calle mientras se escuda en el anonimato de la distancia. En el segundo, Carlos Monsiváis, autor convertido en personaje de la ilustración de la portada de su compilación de crónicas Los rituales del caos (1995), adopta el papel de usuario y espectador del metro de Ciudad de México que toma apuntes - germen o materia prima de sus crónicas urbanassin que las personas circundantes presten atención a su actividad. En ambos casos, el escritor desarrolla una actitud analítica hacia los tipos sociales que habitan la ciudad.

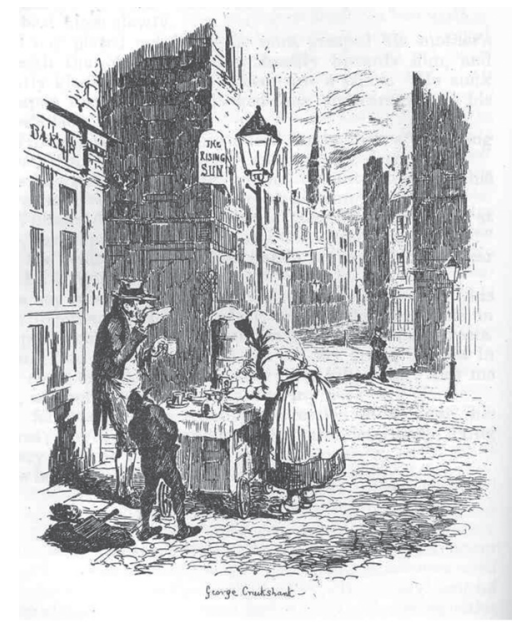

Figura 1. George Cruikshank (1837-1839).

Ilustración de la escena "Streets-Morning". 
El flâneur, que nace con este nombre en las fisiologías y colecciones de tipos sociales costumbristas, también queda visualizado iconográficamente en estos últimos textos. La Physiologie du flâneur (Fisiología del flâneur) ${ }^{5}$, 1841, escrita por Louis Huart, cuenta con ilustraciones de MM. Alophe, Honoré Daumier y Maurisset, como se declara en el frontispicio. En cada uno de los capítulos aparece realizando sus actividades prototípicas. Así, por ejemplo, el primer capítulo lo visualiza vestimentariamente como dandy ocioso (levita, sombrero de copa alta, bastón...); la ilustración de apertura del segundo capítulo lo presenta disfrutando de los animales del zoológico, mientras que en la del cuarto capítulo aparece observando a un hombre que amaestra un perro. Otras dos importantes ilustraciones aparecen en este capítulo: en la primera mira a unas niñas que saltan a la cuerda, mientras en la segunda, absorto en la contemplación del escaparate de un comercio, un carterista le roba su billetera. En el octavo capítulo, el flâneur, en el patio de butacas de un teatro, observa a los espectadores con unos binoculares; persigue a una passante (transeúnte) en el onceavo capítulo; sufre diversos contratiempos en la calle (tropieza, queda empapado por la lluvia, se mancha los pantalones de barro) en el capítulo doce. Dibuja a un muchacho ( gamin) en los muelles del Sena en el capítulo catorce; mientras en el quince observa una función de títeres.

En la historia de la iconografía del flâneur debe destacarse, asimismo, The Natural History of the Idler upon Town (La historia natural del ocioso en la ciudad), 1848, de Albert Smith. Entre las ilustraciones que representan la actividad del flâneur inglés (el Idler), realizadas por Archibald Henning, se encuentran algunas que lo muestran en espacios públicos. En el capítulo cuatro, visita un jardín zoológico; en el cinco, observa un espectáculo óptico; en el seis, contempla, en dos ilustraciones distintas, los escaparates de unas tiendas, mientras que en el once, en lugar de prestar atención a un espectáculo teatral, conversa con algunos espectadores.

También deben considerarse las cincuenta y cinco ilustraciones preparadas por George Cruishanck para la edición de 1839 de Sketches by Boz, de Charles Dickens, ya mencionada. Aunque sólo una de las ilustraciones nos ofrece la figura del flâneur, la perteneciente a la escena Calles-Mañana, ya comentada, la mayoría presenta ilustraciones de escenas callejeras y de sus diversos tipos sociales, como si fueran observadas desde el punto de vista móvil típico del artista callejero ${ }^{6}$.

La iconografía del flâneur establecida por las ilustraciones costumbristas -sobre todo, a partir del código vestimentario que utiliza- ha determinado las interpretaciones de los historiadores del arte a la hora de quedar identificado en la cultura visual decimonónica. De esta manera, cualquier personaje que aparezca en el espacio público con sombrero de copa, levita y bastón, aparentando cierto status económico y disfrutar del ocio, ha sido identificado automáticamente como flâneur, dejando de lado el hecho de que la flanerie, más que un estilo visual, es una actividad, un uso del espacio urbano, un tipo específico de subjetividad. En los historiadores del arte, los códigos visuales iconográficos (específicamente, los perfilados por las ilustraciones costumbristas) ha acabado por determinar todo proceso de identificación del flâneur en la cultura visual decimonónica, como veremos a continuación. Deben complementarse las explicaciones de los historiadores sobre el código vestimentario con el interés hacia la actividad peripatética y visual del personaje representado.

Una escena londinense (1835), de John Orlando Parry, representa la importancia que adquieren los medios de comunicación impresos británicos en el siglo XIX, en especial la publicidad, con la pared llena de anuncios y titulares de papel periódico. Muestra, asimismo, a un carterista que roba la billetera a un observador, que para Rose (2007: 62-64) es un flâneur. Le identifica como tal por su mirada ociosa. En este último aspecto, establece relaciones intertextuales 
entre esta última obra y las ilustraciones de la Fisiología del flâneur (1841), de Huart; de la Fisiología del ocioso londinense, de Smith y Leech (1842), para la revista Punch; y de The Natural History of the Idler upon Town (La historia natural del ocioso en la ciudad), 1848, de Albert Smith. En todas ellas aparece el motivo del robo de la billetera a un hombre que observa un escaparate.

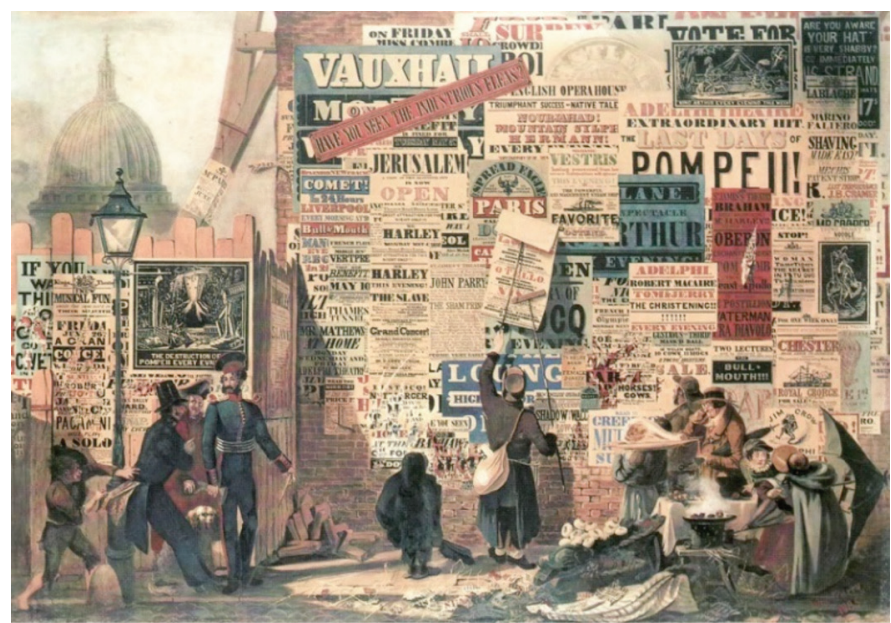

Figura 2. Una escena londinense (1835), de John Orlando Parry

Un cuadro importante tanto en la historia de la representación del flâneur como de la multitud es La música en las Tullerías, (1862), de Edouard Manet, título por lo demás irónico, ya que en lugar de mostrar a los músicos (es decir, la orquesta), visualiza a su auditorio, compuesto de flâneurs y flaneuses. Interesa destacar que los personajes masculinos del cuadro se encuentran vestidos con los atributos típicos del flâneur, del burgués ocioso (chistera, levita, bastón...). Herbert centra su análisis del cuadro en la actitud asumida por los personajes; considera que el propio Manet, Baudelaire y Aurelien Scholl, que aparecen representados en el cuadro, "ocupan un espacio semejante a un escenario, apropiado a la idea de que París era un teatro en el que cada uno siempre debía adoptar un papel" (1988: 37). De hecho, el público espectador se observa entre sí en este cuadro. Son 'actores' que se muestran mutuo interés. Es algo típico del ocioso: en el teatro, el flâneur encuentra su principal objeto de atención en el patio de butacas y en los palcos, no en el escenario. Los personajes del cuadro de Manet, explica Körner, "[s]on flâneurs que en la imagen conciertan una cita; que no están allí para escuchar un concierto, sino para ver a la multitud, que por lo demás, en la pintura de Manet, sólo están allí para ver a otros seres humanos" (1996: 49). Se trata de un cuadro que tematiza el juego de miradas emprendido por los personajes representados. Como explica Körner:

\footnotetext{
Lo que se sitúa en el centro del cuadro es la mirada como tema decisivo, la mirada siempre respondida, que nunca se mantiene sobre su objeto; el que mira siempre es objeto de una mirada, así como finalmente también nosotros, los espectadores del cuadro, estamos atrapados en esta red. Constantemente somos observados por las figuras de los cuadros de Manet, cuyas miradas, en indiferente y provocadora ausencia de propósito, se fijan en nosotros. (1996: 40)
}

La música en las Tullerías es un cuadro que Körner (1996: 49) considera como la primera imagen, en rigor, del individuo moderno individualizado frente a la multitud: no se trata de un cuadro de una multitud o del individuo que sobresale del trasfondo de esta última, sino que representa al individuo en la multitud 7 . Debe elogiarse en Körner, al distinguir al flâneur y a la flanuese, su decisión de centrarse en el juego de miradas, en lugar del código vestimentario de los personajes. 
Macey (2000: 131) considera que es flâneur el personaje que aparece en el cuadro El puente de Europa (1876), de Gustave Caillebote con sombrero alto y levita. Gira la cabeza para observar a la mujer que acaba de sobrepasar, con lo que se evidencia uno de los mayores atractivos para esta figura masculina, la posibilidad del encuentro erótico con una mujer desconocida. A la misma conclusión llega Herbert (1988: 23-4; 34) al afirmar que este hombre está reconociendo intencionalmente su entorno; además, categoriza al obrero recostado en la barandilla del puente como badaud, es decir, como un mirón ocioso. Más que el código vestimentario, es la mirada y la trayectoria la que permite identificar como flâneur a este personaje.

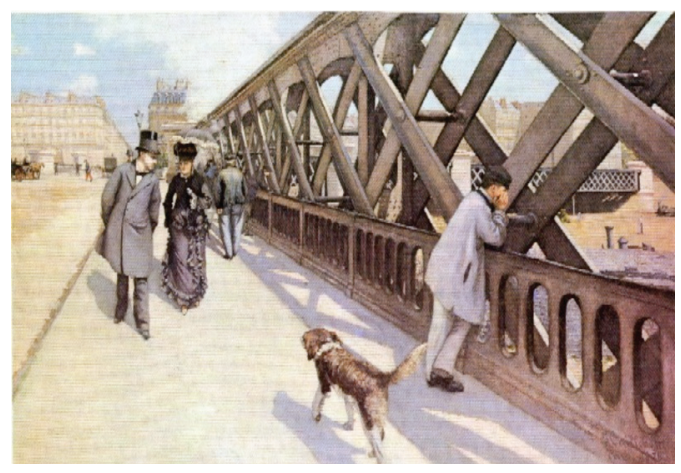

Figura 3. El puente de Europa (1876), de Gustave Caillebotte

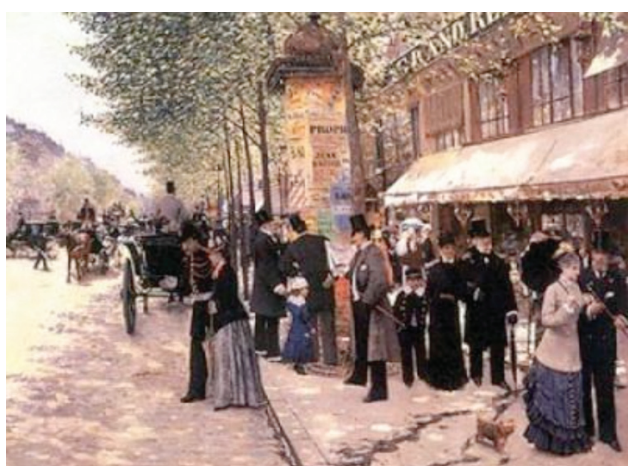

Figura 4. París, en el bulevar (entre 18781882), de Jean Béraud

Por su parte, el caballero con chistera, levita y bastón que aparece en el centro del cuadro Paris, en el bulevar (1878-1882) de Jean Béraud ha sido identificado flâneur por Herbert (1988: 34) al señalar que, rodeado de transeúntes, interpreta el entorno. Considero, por mi parte, que la imagen no ofrece indicadores de esta actitud reflexiva. Más bien, la interpretación de Herbert aparece más que todo fundamentada en el código vestimentario utilizado por este personaje, relacionado por lo general con el flâneur. Asimismo, para Herbert (1988: 35), la indiferencia demostrada por el vizconde Lepic en La plaza de la concordia (1875), de Degas, junto con su vestimenta (chistera y levita), son indicadores que le permiten definirlo claramente como flâneur; la misma actitud indolente también permite identificar a James Tissot, según Herbert, como representante de este tipo social, en el cuadro del mismo nombre, James Tissot, (1868), de Edgar Degas, aunque se encuentra recostado en el asiento de un espacio interior, el estudio del pintor.

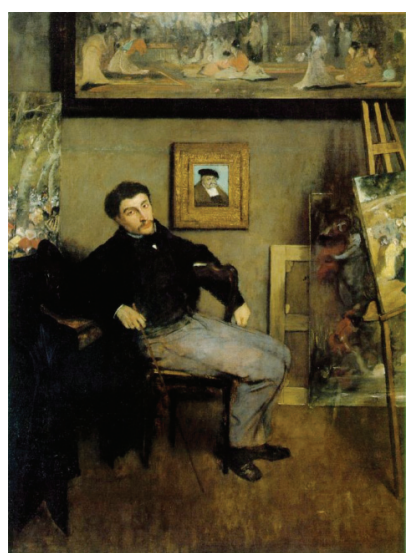

Figura 5. James Tissot (1868), de Édgar Degas

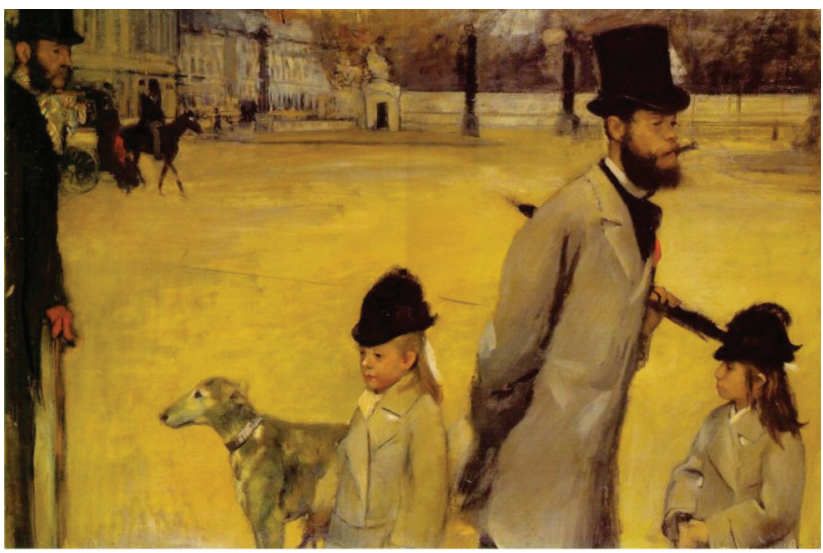

Figura 6. La plaza de la concordia (1875), de Edgar Degas 
Surge una pregunta: ¿cómo identificar, desde la focalización externa típica de la cultura visual, a un flâneur? Considero que las interpretaciones de Herbert se encuentran demasiado determinadas por el código vestimentario atribuido al flâneur desde los textos costumbristas franceses de los años treinta y cuarenta del siglo XIX, así como por la actitud de indolencia externa (aunque su mente interprete activamente el entorno) que por lo general se le atribuye a este tipo social. Se asume que los personajes de las escenas callejeras de algunos pintores impresionistas, por el hecho de poseer estos dos últimos códigos culturales (vestimenta y gestualidad), deben ser identificados necesariamente como flâneurs, cuando más bien deben investigarse, sobre todo, la trayectoria indolente y la mirada curiosa. La asociación excesiva entre código vestimentario y flanerie también es planteada por Chang (2006: 67), quien al analizar el retrato de Théodore Duret (1868), de Edouard Manet, considera que los guantes, el bastón para caminar y el aire seguro convierten a este personaje en un conocedor de los espacios urbanos. Desde mi punto de vista, planteo que si el personaje camina sin intencionalidad práctica, desde una actitud ociosa, pero con una actitud alerta hacia su entorno, se puede identificar como flâneur.

Por otra parte, Rose (2007: 57-58) considera al hombre que observa un escaparate en el cuadro Ante el escaparate (1864), de Carl d'Unker-Lützow, como ejemplo de flâneur. En este caso, podemos apoyar la propuesta de Rose, ya que, sin tomar en cuenta el código vestimentario que utiliza, se trata de un ocioso que se detiene a observar el escaparate de un comercio, actividad típica de este tipo social ${ }^{8}$. La misma comparación implícita con las ilustraciones costumbristas la establece Rose (2007: 58) al identificar como flâneur a un caballero observador con bastón y chistera en el cuadro Vista de la parte trasera de las casas en el Castillo de la Libertad (1855), del alemán Eduard Gaertner, mientras que en La calle de la Parroquia (1831), del mismo pintor, singulariza una figura más ambivalente, que puede quedar identificada tanto en el papel de flâneur como en el de Eckensteher (literalmente, el hombre que se para en una esquina), este último un tipo representativo del Berlín decimonónico (también de París y Madrid'), el ocioso desempleado que 'mata el tiempo', del que, asimismo, existe un dibujo de Franz Dörbeck (alrededor de 1832).

Ya vimos que Baudelaire considera a Guys un flâneur. Ahora, cabe responder a la pregunta ¿representa flâneurs y flaneuses en sus producciones? Rose señala que estas últimas "han mostrado a hombres y mujeres callejeando o cabalgando en carruajes a través de París" (2007: 56). Debe precisarse que, más que flanear, pasean. Son grupos o parejas de burgueses que transitan por los espacios seguros de los parques, sin que se les represente en una actividad visual específica.

En un estudio más panorámico, y con la utilización de las categorías pertinentes, Forgione (2005: 664-687) identifica, diversas modalidades de tipos sociales que transitan por las calles de París como transeúntes, paseantes, flâneurs, flaneuses, badauds, en la pintura francesa desde 1860 hasta 1900. Adopta tres criterios de análisis: la mirada de los personajes representados, su uso del cuerpo y, por último, indicadores externos de su vida psicológica interior $^{10}$. Estas categorías, y no el código vestimentario del burgués ocioso, asociado al flâneur en la primera mitad del siglo XIX, deben ser las que nos permitan su identificación.

Aunque todavía no ha recibido especial atención por parte de los analistas de la flanerie, Jean Béraud es el pintor por antonomasia de las flaneuses que callejean por los espacios públicos de París en el último cuarto del siglo XIX. Un ejemplo es Quiosco de Paris (1882), que representa a dos flaneuses: una de ellas observa detenidamente un afiche colocado en una columna de anuncios (en el lado opuesto, un flâneur realiza la misma actividad), mientras que una segunda mujer burguesa atraviesa la calle. En otros cuadros de Jean Béraud, también de las dos últimas 
décadas del siglo XIX, identificamos otras passantes/flaneuses, por ejemplo en El Señor y la Señora Galin delante del Club de Jockey, pues frente a este matrimonio aparece una transeúnte solitaria burguesa o pequeñoburguesa (les separa una columna de anuncios); El Puente Nuevo nos ofrece en primer término a una mujer joven que camina ensimismada; en Cerca de la Torre Eiffel, aparece una mujer burguesa que observa esta estructura con binóculos; En la Madelaine, una mujer sin compañía sale de la iglesia; en Caminando por París transitan por la acera dos empleadas de tienda vestidas de negro; en Dama a la moda saliendo de la Casa Doucet, una consumidora, cargada de paquetes, está a punto de tomar un coche de caballos; en jA casa, cochero!, una burguesa toma este último medio de transporte. La asociación de ciertos oficios femeninos 'bajos' con el intercambio erótico mediado por el dinero aparece en La modista en los Campos Elíseos, donde el personaje femenino, que no pertenece al grupo de las mujeres 'respetables', se sube las enaguas, mientras es observada en segundo plano por un flâneur que tiene evidentes intenciones sexuales; La Espera también sugiere este tipo de intercambio: en una calle solitaria, una mujer en primer plano intercambia una mirada con un hombre al fondo.

Existen escasos estudios que hayan tratado de identificar a la passante (desde la mirada del flâneur, es la mujer transeúnte) o a la flaneuse (representación, dotada de una subjetividad propia, de la mujer que camina) en la cultura visual occidental. Entre los estudios realizados se encuentra el de Iskin (2003: 333-356), dedicado a los afiches franceses de la década de 1890 que muestran a mujeres burguesas y pequeño burguesas en el uso del espacio público sin ningún tipo de compañía masculina. Se trata de afiches publicitarios dirigidos a estos sectores sociales como consumidores potenciales.

En la cultura visual parisina de tercer tercio del siglo XIX también se identifican mujeres burguesas sin compañía masculina en espacios 'seguros', en términos de la moral sexual pública, como parques y teatros. Thomas (2006: 33-48) afirma que Mary Cassatt, en cuadros como Conduciendo (1881); Berthe Morisot, en Un día de verano (1879) y Edouard Manet, en Música de las Tullerías (1862), representaron mujeres como sujetos independientes y activos, y como consumidoras y observadoras creativas de la cultura moderna; considera que, si bien no se pueden considerar como flaneuses en toda regla, ya que se traslada el espacio simbólico del hogar a lugares públicos 'seguros' como los parques, estos personajes femeninos, al asumir cierta movilidad, uso y visualidad independiente del espacio público (no están acompañadas de hombres), contribuyen a minar el modelo del flâneur como único representante del desplazamiento libre. Si bien estos cuadros ofrecen más bien paseos, como sucede también en Luxembourg Gardens at Twilight (Los jardines de Luxemburgo en el ocaso), 1879, de John Singer Sargent, las mujeres representadas, en todo caso, hacen un uso interpretativamente activo del espacio (observan, manejan vehículos, transitan por los senderos de los parques...).

La consumidora que visita sola o en compañía femenina un almacén de novedades ha sido definida por algunos investigadoras (Friedberg 1993 p. ej.) como flaneuse. ¿Se puede identificar en la representación visual de los espacios comerciales, si es que estos últimos han sido objeto de atención? En este sentido, D’Souza (2006: 129-147) responde a la pregunta: ¿por qué los impresionistas nunca pintaron los grandes almacenes? Raramente aparecen las transacciones de compra y venta entre cliente y empleado; el comercio queda representado indirectamente por medio de la moda, la decoración o el ocio. Entre los escasos ejemplos se encuentran las pinturas y los dibujos de las sombrererías de Edgar Degas (dieciséis en total).

Dos son los motivos que explican, para D'Souza, la ausencia de los grandes almacenes en las obras de los pintores impresionistas: la exhibición del arte canónico en estos espacios 
(en los vestíbulos, p.ej.), embarcados como estaban en la popularización y comercialización del Arte académico (simbiosis de la que renegaban como artistas 'marginales') y, segundo, su apreciación simbólica de estos lugares como espacios 'femeninos'. D’Souza señala que algunos cuadros de sombrererías de Degas asumen precisamente el punto de vista de un transeúnte, el flâneur masculino, que observa hacia el interior de la sombrerería, espacio femenino. Habrá que emprender una investigación en el futuro sobre los motivos de la ausencia del espacio comercial en las pintoras impresionistas.

\section{El flâneur y el cine}

Las relaciones entre el flâneur y el cine se bifurcan en dos direcciones. En primer lugar, se puede interpretar el punto de vista utilizado por la cámara como flanerie tecnológicamente mediada. En segundo lugar, podemos analizar, en el marco de la historia del cine, la presencia del flâneur o la flaneuse en películas de ficción y documentales.

\subsection{La mirada de la cámara como flanerie urbana}

Es muy fácil identificar la mirada de la cámara con la flanerie urbana, con la visión del flâneur, sobre todo cuando se toma en cuenta que ambas actividades se caracterizan por la movilidad: es decir, son actividades peripatéticas que desarrollan una visualidad fragmentaria, caleidoscópica. Las teorías realistas del cine (Béla Balázs, Siegfried Kracauer, Dziga Vertov), estrechamente vinculadas con la práctica del cine no narrativo de tipo documental, son las propuestas que más han utilizado los presupuestos de la mirada del flâneur para interpretar la ontología del arte cinematográfico. Minden establece este vínculo

\footnotetext{
Donde la yuxtaposición de la imagen móvil no está subordinada a un argumento, y donde los cortes son evidentes, en lugar de quedar ocultos en los pliegues de una narración en desarrollo, el efecto puede ser semejante a la experiencia subjetiva de la ciudad, es decir, una sucesión de imágenes y ángulos diversos que construye una percepción en fuerte contraste con la percepción unificadora y uniforme de un pueblo o un paisaje; una percepción radicalmente más rápida y menos continua que la promovida por formas tradicionales de literatura, escultura y pintura. (1985: 203)
}

Siegfried Kracauer, en su Teoría del cine, publicada en 1960, perteneciente a las teorías realistas, ha reflexionado sobre las similitudes entre la mirada del flâneur y el registro visual de la cámara cinematográfica. Se dan, sobre todo, con el género documental y, en este último, en el subgénero de la sinfonía urbana, que registra las variaciones en el ritmo de las actividades callejeras. La cámara es un 'trapero' que recoge, reúne y organiza las impresiones dispersas de la calle. Las similitudes también deben extenderse al director del documental, no sólo a la cámara: de la misma manera que los pintores impresionistas han sido definidos como flâneurs, el documentalista urbano, por derecho propio, también lo es. Su intención es preservar la poesía en movimiento de las calles (Gleber 1999: 155).

El cine comparte el mismo registro de la realidad que la fotografía. Kracauer considera que el cinematógrafo comparte cuatro de sus características intrínsecas con la imagen fija fotográfica: lo desteatralizado, lo fortuito, lo interminable, lo indeterminado y 'el flujo de la vida' (1996: 89-106). A su vez, el cinematógrafo comparte con la flanerie estos mismos atributos... Se encuentran en la calle, no en la solitaria, sino en la atestada de transeúntes. La calle, declara Kracauer, 
no sólo es el conjunto de impresiones fugaces y de encuentros casuales, sino el sitio donde el flujo de la vida ha de autoafirmarse. De nuevo, debe pensarse principalmente en la calle urbana, con sus muchedumbres anónimas en perpetuo movimiento. [...] Lo que se le aparecen [al espectador] no son tanto individuos de contornos nítidos, empeñados en tal o cual afán concreto, como un vago tropel de figuras esquemáticas, totalmente indeterminadas. (1996: 103)

La teoría realista de Kracauer es, en este sentido, impresionista, fundamentada en las impresiones fugaces que recibe la retina. A continuación, Kracauer afirma que al flâneur también le hechiza y embriaga el flujo de la vida urbana (1996: 103-104). Además, el espectador, al 'ver' lo que la cámara ha registrado, también se siente atraído por los fenómenos que han embriagado previamente, tanto al aparato cinematográfico, a la cámara, como al flâneur. Kracauer establece equiparaciones entre la mirada del individuo que callejea y la experiencia ensoñadora del espectador en la sala de cine. El espectador recuerda a este tipo social urbano

\footnotetext{
en su susceptibilidad respecto de los fenómenos transitorios de la vida real que pueblan la pantalla. [...] Junto con los sucesos fragmentarios incidentales, estos fenómenos -taxis, edificios, transeúntes, objetos inanimados, rostros- estimulan presumiblemente los sentidos del espectador y le proporcionan material para soñar. A través de su propia preocupación por la realidad que registra la cámara, el cine permite, sobre todo al espectador solitario, llenar su propio yo [...] con imágenes de la vida entendida como tal: una vida brillante, alusiva, infinita. (1996: 220)
}

La experiencia de ir al cine también es relevante en Kracauer, cuyos análisis sobre este tópico se desarrollan en el marco de sus investigaciones sobre la cultura de la diversión [Zerstreuung] en la República de Weimar ${ }^{11}$. Esta cultura es indagada en textos como El ornamento de masa, El culto de la diversión o Las vendedoras de los comercios van al cine, donde establece una homología entre los argumentos escapistas de las películas y las audiencias femeninas de empleadas jóvenes.

¿Qué procedimiento cinematográfico específico, por antonomasia, representa el flujo de la vida de forma equivalente a la actividad del flâneur? La respuesta se encuentra en el reencuadre móvil, sobre todo en una de sus modalidades, el plano secuencia, que puede equipararse a la percepción de una persona que camina. Gleber ha visto esta relación al señalar que la movilidad del flâneur "revela afinidad con las largas y extensas tomas de una cámara cuyo movimiento se aproxima y captura las emanaciones visuales del mundo exterior" (1999: 152). Un ejemplo nos lo ofrece el plano subjetivo móvil al inicio de A propósito de Niza (1930), de Jean Vigo, orientado hacia la acera del paseo marítimo. En todo caso, otra técnica también se asemeja a la visualidad móvil del flâneur, sobre todo en espacios atestados de gente y tráfico. Nos referimos al montaje rítmicamente veloz, fragmentado en multitud de planos, que permite equiparar la mirada de la cámara con la experiencia del observador en calles transitadas. Un ejemplo nos lo ofrece $E l$ hombre de la cámara (1929), de Dziga Vertov durante gran parte del metraje.

\subsection{Las sinfonías urbanas como flanerie}

El cine no sólo nació como un espectáculo urbano para los transeúntes que deseaban convertirse en mirones; también las primeras películas representan escenas callejeras. Es sorprendente la popularidad de este espacio, destaca Gunning en las primeras exhibiciones, que "presentaban una puesta en abismo de audiencias que llenaban teatros de vaudeville, procedentes de las transitadas calles urbanas, para ver proyectadas sobre la pantalla transitadas calles urbanas" (1997: 33). 
Los documentales urbanos siempre han asumido la mirada de la flanerie: con mayor o menor ficcionalización, la cámara registra el espacio público, protagonizado por acontecimientos fugaces, medios de transporte y comercios, donde domina la reserva mutua y el fetichismo de la mercancía (Dimendberg 1997: 62-93) ${ }^{12}$. Paradigma son las llamadas sinfonías urbanas, que representan el ritmo diario de la urbe, propio de la modernidad ${ }^{13}$.

Latinoamérica cuenta con una sinfonía urbana, São Paulo: sinfonía de uma cidade (1928), que Shohat y Stam (2002: 284) ofrecen como ejemplo de cine vanguardista en el Tercer Mundo del primer tercio del siglo XX. De las tres grandes sinfonías urbanas, Berlín, la sinfonía de una gran ciudad (1927) de Walter Ruttmann, El hombre de la cámara (1929) de Dziga Vertov, y Nada más que las horas (1926) de Alberto Cavalcanti, los investigadores siempre han destacado el carácter predominantemente formalista -y poco crítico socialmente- de las dos primeras, frente a la última. Cuando el cineasta prefiere utilizar el enfoque de la sinfonía urbana, inevitablemente se centrará en el ritmo visual, en la duración de los planos y en los espacios ligados a las actividades diarias en la sociedad industrializada. Ahora bien, este género no está cerrado a la dimensión social. Nada más que las horas es una sinfonía urbana socialmente crítica que se interesa en la representación de la vida cotidiana de individuos singularizados, y no tanto en el ritmo que imponen las estructuras económicas y sociales metropolitanas.

Hito importante en la historia de las sinfonías urbanas es Berlín, la sinfonía de una gran ciudad. Se trata de utilizar la 'transversalidad' como principio organizador. Se realizan diversos cortes transversales: sobre las horas de un día, las diferentes clases sociales, profesiones y oficios, y modalidades de ocio y de trabajo... Como sucede con otros documentales urbanos, algunas escenas parecen estar dramatizadas, es decir, preparadas de antemano: la más evidente es la escena de la mujer suicida. Este documental se encuentra dividido en cinco actos, temporalmente organizados. Cada uno se inicia con el fotograma de un reloj que visualiza una hora diferente del día. Utiliza una técnica futurista, muy evidente, por ejemplo, en su introducción, cuando la cámara, situada en un tren, se acerca desde el campo al centro de la ciudad. Está imbuido de la estética de la 'Nueva Objetividad' y ha sido considerado más formalista que las demás sinfonías urbanas ${ }^{14}$.

También es un documental formalista, claramente futurista, El hombre de la cámara. Scherpe (1989: 167) destaca su puesta en escena. En gran medida documental metalingüístico, ya que exhibe el proceso de su producción, también pertenece a la modalidad de observación, más específicamente de observación callejera ${ }^{15}$. Registra un día en la vida de los soviéticos, desde el amanecer hasta las últimas horas de la tarde. Rodada en Moscú, Odessa y San Petersburgo, el documental logra construir, simbióticamente, una ciudad soviética prototípica. Su realismo queda sometido a procedimientos vanguardistas de distanciamiento reflexivo: la cámara y el camarógrafo aparecen constantemente; se detiene una escena callejera y se muestra a la editora organizando los fotogramas; se utiliza la pantalla partida en diversas imágenes urbanas (pretende captar la simultaneidad de las actividades que ocurren en diversos espacios de la ciudad); se detiene, ralentiza o acelera el ritmo de edición de la imagen... El propósito de Dziga Vertov es equiparar la cámara a la ubicuidad del ojo humano. En ocasiones, al registrar la reacción de los soviéticos ante la presencia de la cámara, el documental nos hace tomar conciencia del carácter voyeurista del cine y, por ende, del espectador.

Nada más que las horas se considera la primera sinfonía urbana en términos cronológicos. Como explica Villanueva (2008: 74), tiene una visión baudeleriana, y no 
whitmaniana (es decir, celebratoria) de la ciudad: Cavalcanti se interesa por el mundo parisino de los traperos, las traperas y las prostitutas; su propuesta ideológica se estructura a partir de la contraposición entre las clases opulentas -los fétards o trasnochadores-, y los trabajadores, mendigos y parias $^{16}$.

En Nada más que las horas, la mirada del flâneur, de la que participa la cámara, queda expuesta en el prólogo de la película: "Esta película no tiene ninguna historia. No es más que un conjunto de impresiones sobre el tiempo que transcurre y no pretende sintetizar ninguna ciudad" (Cavalcanti 1926). El término impresión, utilizado, por ejemplo, por los cronistas modernistas latinoamericanos en la representación de la urbe, así como en las reflexiones sociológicas sobre la modernidad, se asocia a modos perceptivos y a estéticas de carácter no narrativo cuyo principio organizador es, sobre todo, la yuxtaposición. Otro intertítulo reza "Pintores de toda clase ven la ciudad..." mientras diversos fotogramas muestran famosas pinturas de París; seguidamente, aparecen imágenes del París 'real', mientras el intertítulo termina el enunciado precedente: “... pero sólo una sucesión de imágenes puede restituirnos la vida”. Es decir, el mundo del arte representa los espacios mundanos, dedicados al ocio, a la modernidad cultural; en cambio, el documental muestra el París de las callejuelas, la vida de los marginados...

Diversas técnicas experimentales son compartidas por el documental de Cavalcanti con otras sinfonías urbanas. Al igual que en El hombre de la cámara, se utiliza el encuadre con imágenes múltiples, que recuerda la fragmentación de espacios y temporalidades en una ciudad. El montaje asociativo también es un procedimiento compartido por los documentales de Ruttmann y de Vertov.

Complementariamente al tema de las horas del día, ofrecido mediante sintagmas descriptivos, también se aprecian en Nada más que las horas algunos sintagmas narrativos, en los que aparecen personajes que la cámara sigue. Se individualizan algunos personajes; uno de ellos es una prostituta que, al amanecer, busca un último cliente; al caer la tarde, se convierte en cómplice de un proxeneta que mata a una vendedora de periódicos. En otro episodio, una anciana alcohólica observada siempre en picado (nunca se le ve el rostro) deambula por las calles de Montmartre. Al aparecer hasta ocho veces, unifica el transcurso de las horas en el cambiante espacio urbano (Villanueva 2008: 75).

Diversos investigadores han analizado comparativamente estas tres sinfonías urbanas, por lo general entre dos de ellas. Chapman (1979: 37-42) ha realizado un análisis comparativo de Berlín, la sinfonía de una gran ciudad y Nada más que las horas. Concluye que, mientras esta última es un homenaje a los pobres de la ciudad, la primera es un ejercicio formal sobre el ritmo urbano. A las mismas conclusiones llega Hake al plantear que "[s]u principio estructural es la simulación, no la representación; su objetivo último es el placer visual, no el análisis crítico" (1994: 127). Hake (1994: 137) concluye que en este documental berlinés, imbuido de la estética de la Nueva Objetividad, la movilidad social, las diversiones de la cultura de masas y el consumismo exacerbado definen las condiciones de una nueva subjetividad urbana: la procedente de los trabajadores de cuello blanco, fundamentada en la eliminación de las diferencias clasistas. Weihsmann (1997: 19) también se ha encargado de destacar el carácter formalista de Berlín, la sinfonía de una gran ciudad y de El hombre de la cámara, frente a Nada más que las horas, más interesada en el individuo. Minden (1985: 203-208), asimismo, destaca el carácter formalista de Berlin, la sinfonía de una gran ciudad y afirma que su tema no es la capital alemana, sino el proceso de mostrar esta ciudad mediante la elección de las 
imágenes, la duración de las tomas, el ángulo de cámara y las yuxtaposiciones del montaje. Korte (1995: 95) también destaca este sesgo formalista y señala que la yuxtaposición de distintas clases sociales sólo quiere mostrar su coexistencia social.

A propósito de Niza (1930), de Jean Vigo, también es una sinfonía urbana. Se dedica, desde una perspectiva marxista, a denunciar las desigualdades sociales en este balneario francés. Como en Nada más que las horas, se estructura a partir de la contraposición entre riqueza y pobreza y, al igual que El hombre de la cámara; Berlín, la sinfonía de una gran ciudad y Nada más que las horas, se inicia en las primeras horas de la mañana. Utiliza como principal recurso retórico -persuasivo, ideológico- el contraste o antítesis, expresado mediante el montaje asociativo. El inicio del documental nos ofrece fotogramas sobre la preparación de la ciudad para recibir a los turistas: el lavado de las calles, la puesta a punto de las mesas de las terrazas de los restaurantes, la poda de las palmeras de los bulevares... Observamos insertos que muestran a empleados en la acción de pintar y acicalar los grotescos gigantes y cabezudos que saldrán en los festejos callejeros ${ }^{17}$.

La trayectoria de la cámara desemboca en el paseo principal de Niza. En este espacio se aprecia un 'desfile' de burgueses ociosos que pasean, toman una bebida (sentados en las mesas de los bares) o toman el sol. Aunque aparecen pocos obreros y desclasados, con su presencia ocasional es evidente la intención de contrastar la opulencia ociosa y la pobreza. Destacan diversas escenas, como aquella en la que un burgués literalmente se quema por la sobreexposición a los rayos solares (se trata de una dramatización), o aquella en la que el cuerpo de una mujer queda convertido, literalmente, en un maniquí al exhibir consecutivamente diversos vestidos (mediante la técnica del stop motion, en otro caso de dramatización). Este último ejemplo se refiere a la fetichización de la mercancía en la sociedad burguesa: el cuerpo humano sólo es soporte para la exhibición de la ropa. Se alternan, además, planos de un cementerio con planos de la alegría de un carnaval callejero. Asimismo, se contrasta la arquitectura Art Decó de los hoteles con la estrechez de las callejuelas, o las escenas de un desfile militar con las de un cementerio (con la intención de argumentar que el militarismo simboliza la muerte).

Regen (Lluvia), 1929, de Joris Ivens, también es una sinfonía urbana cuya cámara asume la mirada de la flanerie. Retrata la caída de la lluvia en las calles de Amsterdam. El inicio muestra la placidez del buen tiempo; de pronto sopla un fuerte viento que obliga a cerrar las ventanas y a proteger los escaparates. Asimismo, asume la mirada del flâneur el cortometraje El puente (1927-1928), aunque no se trata de una sinfonía urbana; es un ejercicio formalista sobre los movimientos mecánicos de un puente levadizo. Al inicio aparece un camarógrafo que usa su cámara (la gira hasta posicionarse frente al espectador): Ivens pretende destacar que las imágenes no muestran la realidad, sino que constituyen una construcción discursiva procedente de una instancia productora ${ }^{18}$. Predominan los planos de las partes del puente, que ofrecen una visión novedosa (estética) de este último, y planos panorámicos del río y la ciudad ${ }^{19}$. Punto central en El puente es la poesía producida por el ritmo del movimiento de los engranajes, por la 'danza' milimétricamente planificada del puente. Una vez que el puente levadizo desciende y se acopla nuevamente a la línea férrea, los trenes lo traspasan y continúan su camino. Se trata de un experimento más que todo formal.

Setenta y cinco años después de la película de Ruttmann, en el 2002, el documentalista Thomas Schadt realizó otro documental sobre la capital alemana, siguiendo el mismo modelo, Berlín: Sinfonía de una gran ciudad. Ward (2007: 155-177) ha realizado un análisis detenido de este documental. Considera que recurre a la alusión intertextual de películas como El 
cielo sobre Berlín, de Wim Wenders; Metrópolis, de Fritz Lang; o el mismo precedente de Ruttmann. Concluye que, frente al documental de su predecesor, centrado en ofrecer una mirada estética 'futurista' (el ritmo de la ciudad y de la industrialización), la propuesta de Schadt ofrece una visión crítica, incluso al citar como homenaje el documental de Ruttmann. Así, en el documental de Schadt, mediante montaje asociativo, se yuxtaponen los fotogramas de unos animales que comen en el jardín zoológico y los de unos comensales humanos que almuerzan en un restaurante de lujo. Por implicatura ha sido elaborada una yuxtaposición y una argumentación políticamente crítica que ya se encontraba en el documental de Ruttmann. Según Ward, se ofrecen al espectador imágenes revestidas de valores pertenecientes a la memoria crítica al empotrar imágenes fijas del pasado (caso del Reichstag) en las imágenes del Berlín contemporáneo, o al utilizar la yuxtaposición irónica de contrastes urbanos en una ciudad que, de por sí, se caracteriza por ofrecer restos de un pasado insertado en la arquitectura del presente.

Frente a las sinfonías urbanas, otras películas buscaron en las década del veinte y del treinta retratar momentos específicos de la cotidianeidad urbana o de la vida de algunos ciudadanos. Podemos mencionar, desde diferentes propuestas estéticas e ideológicas, tanto en la ficción como en el documental, la estadounidense Manhattan (1921) de Paul Strand y Charles Sheeler; las alemanas La calle (1923) de Karl Grune, y La callejuela triste (1925) de Georg Wilhelm Pabst; o la francesa Duerme París (1925) de René Clair. Además, Poppe (2009: 49-69) ha interpretado como flanerie el desempeño de la cámara en el espacio público en la película argentina Los tres berretines (1933), del Equipo Lumiton.

París también cuenta con otros documentales sobre sus calles, por lo general desde la mirada turística. En los años veinte se pueden nombrar Paris Express (1928), de Marcel Duhamel y Pierre Prévert, o Armonías de París (1928), de Lucie Derain. Juan Myriam (2004: 291-314) se ha ocupado de analizar estos documentales y ha establecido su geografía simbólica, fundamentada en la circulación, el ritmo y la velocidad de la modernidad y las atracciones y curiosidades.

En el cine alemán posterior a la Segunda Guerra Mundial, Fisher (2005: 461-480) ha identificado al flâneur en Los asesinos están entre nosotros (1946) de Wolfgang Staudte. Décadas después, aparece esta figura en El cielo sobre Berlín (1987) y su segunda parte, Tan cerca, tan lejos (1993) ambas de Wim Wenders. En estas dos últimas películas, dos ángeles deambulan en la capital alemana. Le buscan un sentido a la existencia humana. Siempre asumen un punto de vista distanciado de los acontecimientos urbanos. Cuando se convierten en humanos, su principal actividad es, además, deambular. Por su parte, Hamm-Ehsani (2004: 50-65), ha analizado Corre, Lola, Corre (Lola rennt) 1998, de Tom Tykwer, como renovación del género de la sinfonía urbana (encuentra muchos puntos de contacto con la película de Ruttmann) al representar Berlín en un contexto postmoderno de globalización capitalista.

El cine inglés también ha actualizado la figura del flâneur. London (1994) de Patrick Keiller, presenta el callejeo de una pareja, Robinson y el narrador. Intentan localizar los sitios donde conocidos artistas y escritores británicos protagonizaron episodios de su vida, a través de la indagación del pasado 'oculto' de la capital británica; se yuxtapone a esta búsqueda el comentario sobre ciertos acontecimientos que acapararon la atención en el año de 1992, como fue el caso de un atentado terrorista del IRA (Donald 1999: 184). Es un experimento que mezcla la ficción del comentario de la voz en over con imágenes documentales. El inicio de Following (1998) de Christopher Nolan incorpora a un personaje protagonista que responde a las búsquedas tradicionales del flâneur. Se trata de un joven escritor que sigue a 
los transeúntes y se introduce en sus casas con el objetivo de encontrar materiales (historias) para su escritura. Por otra parte, Croupier (1998), de Mike Hodges, presenta a un escritor en 'sequía creativa' que acepta un trabajo en un casino con el objetivo, al igual que en la película de Nolan, de obtener temas para su escritura. Aunque no 'flanea' por las calles, sus inferencias interpretativas, aplicadas a los jugadores de un casino, son idénticas a las que realiza el flâneur en los espacios abiertos.

Los estudios fílmicos también han investigado a la flaneuse. La inscripción de los personajes femeninos en el espacio urbano, considerado como fuente de ansiedad, ha motivado parte de la obra de Michelangelo Antonioni, sobre todo de La noche (1963). Murphy (2006), por su parte, ha analizado la flanerie que las protagonistas de Vacaciones en Roma (1953) de William Wyler, y Lost in traslation (2003) de Sofia Coppola, emprenden en las calles de Roma y de Tokio, donde encuentran y traban amistad con hombres desconocidos, en contactos más caracterizados por la necesidad de comunicación que por el encuentro sexual. Por su parte, Hottell (1999: 52-71) analiza la flanerie femenina en dos películas de Agnes Varda: La felicidad y La una canta; la otra, también. Asimismo, Hegel (2007) se acerca a Marsella, de Angela Schanelecs, protagonizada por una flaneuse, en este caso, Sophie, fotógrafa de profesión.

\section{La flanerie y la fotografía}

Si nos referimos a las relaciones entre la flanerie y la fotografía, los tópicos de investigación son similares a los del cine. También el punto de vista adoptado por la cámara fotográfica ha sido equiparado a la mirada peripatética del flâneur. En una época tan temprana como 1857, menos de veinte años de su invención, Victor Fournel llamó daguerrotipo móvil al flâneur. En particular, comparó la actividad perceptiva del flâneur con la de la cámara fotográfica:

\footnotetext{
Es un daguerrotipo móvil y apasionado que guarda las menores huellas, y en el que se reproducen, con sus reflejos cambiantes, la marcha de las cosas, el movimiento de la ciudad, la fisonomía múltiple del espíritu público, de las creencias, de las antipatías y de las admiraciones de la multitud. (1857: 268)
}

Brand (1991: 165), después de señalar que ya en el siglo XIX los escritores periodistas establecían equiparaciones entre la mirada del flâneur y la del fotógrafo (incluso comenzaron a sustituir el término sketch o esbozo por el de fotografía), precisa que ambos papeles sociales reivindicaban el hecho de ofrecer imágenes no mediadas de la realidad. El flâneur es un daguerrotipo móvil que encontrará años después, con la llegada del cine, la posibilidad de poner en movimiento sus imágenes. Así se demuestra que las nuevas condiciones perceptivas urbanas del siglo XIX no sólo estuvieron simbolizadas en tipos sociales como el flâneur, sino también por artefactos de la cultura popular visual, como la cámara fotográfica. En consecuencia, ambos son el resultado (creación en el primero, invención en el segundo) de las condiciones perceptivas promovidas por la ciudad.

\footnotetext{
la nueva mirada del hombre en la ciudad no presupone la fotografía; es más bien la fotografía la que presupone una nueva mirada. En otros términos, la estimulación de la vida moderna, la multitud, la variedad de los objetos, la vida trepidante, han transformado la mirada y al observador. La fotografía marcha, pues, en concierto con el nuevo observador estético de la ciudad moderna, el flâneur. (1990: 41)
}

No se ha investigado la presencia del flâneur o de la flaneuse en la historia de la fotografía, como sí ha sucedido en el caso del cine. En cambio, el fotógrafo ha sido identificado en diversas ocasiones desde este papel social. Susan Sontag, ya en el siglo XX, reconoció al fotógrafo la condición de flâneur, y a la fotografía la posibilidad de compartir la mirada propia de la flanerie: 
Al observar la realidad de otra gente con curiosidad, distanciamiento, profesionalismo, el ubicuo fotógrafo opera como si esa realidad trascendiera los intereses de clase, como si su perspectiva fuera universal. De hecho, la fotografía al principio se consolida como una extensión de la mirada del flâneur de clase media [...] El fotógrafo es una versión armada del paseante solitario que explora, acecha, cruza el infierno urbano, el caminante voyeurista que descubre en la ciudad un paisaje de extremos voluptuosos. (2007: 84)

Para Sontag, la actitud antropológica del fotógrafo-flâneur es la del observador. Su ideología es similar a la ofrecida por Baudelaire en El spleen de París, en su descripción de la Otredad urbana, en lugar de la visión triunfalista de la modernidad, presente en El pintor de la vida moderna, con su visión del flâneur que participa en la corriente de transeúntes del bulevar: "Al flâneur no le atraen las realidades oficiales de la ciudad sino sus rincones oscuros y miserables, sus pobladores relegados, una realidad no oficial tras la fachada de vida burguesa que el fotógrafo «aprehende» como un detective aprehende a un criminal" (2007: 85).

Los fotógrafos que la ensayista norteamericana define como flâneurs son más bien los que se interesan por los espacios más antiguos y degradados de las grandes urbes, o aquellos que 'retratan' los barrios ‘bajos'. Los modelos de Sontag (2007: 85) son Paul Martin (calles de Londres), Arnold Genthe (barrio chino de San Francisco), Atget (las callejuelas y los oficios olvidados de París), Brassaï (el sexo y la soledad en el París nocturno) y Weegee (calles populares de las ciudades norteamericanas).

Friedberg (1993: 31), caracteriza como flâneur a Nadar, el famoso fotógrafo del París de mediados del siglo XIX. Eugène Atget, que comenzó a fotografiar las callejuelas parisinas y sus respectivos tipos sociales a finales del siglo XIX (sin interés por los bulevares), no sólo es apreciado como fotógrafo flâneur por Sontag, sino también por Gomella (2009: 67), quien destaca el aprecio que obtuvo en los círculos surrealistas. Asimismo, la llamada fotografía humanista, entre cuyos participantes se cuentan Robert Doisneau y Henry-Cartier Bresson, entre otros, en búsqueda del 'instante decisivo', también son analizados por Gomella (2009: 68-70) desde la figura del fotógrafo flâneur.

Una táctica común, por parte de los investigadores, es utilizar un personaje o un tipo social específico como metáfora de una modalidad específica de representación visual del espacio público urbano; así, la mirada panorámica sería típica de Asmodeo, la mirada a nivel de la calle, típica del flâneur. A partir de este presupuesto, la polarización de la metrópoli occidental en la segunda mitad del siglo XIX como espacio del consumo o del caos urbanístico orientado a la criminalidad no favorece, en este marco temporal, la mirada distanciada del flâneur como paradigma conceptual dominante. Shaya (2004: 41-77), en su análisis de Le petit journal, demuestra que la prensa parisina de la segunda mitad del siglo XIX se dirige al lector mirón; y no sólo interpela explícitamente a sus lectores -identificándose como portavoz de sus intereses- como observadores urbanos ávidos de curiosidad, es decir, como badauds o mirones (con lazos solidarios ante los horrores urbanos), sino que también representa los acontecimientos criminales, tanto verbal como gráficamente, desde el punto del punto de vista de estos últimos, como si el periódico y el reportero gráfico fueran testigos presenciales que estuvieran escrutando emotivamente la escena de los hechos. No en todo tipo de prensa popular la mirada del flâneur entra en declive en la segunda mitad del siglo XIX. Gretton (2006: 94-112) considera que los illustrated weekly magazines (revistas semanales ilustradas) de Francia e Inglaterra, entre 1860 y 1910, imitaron en sus ilustraciones y fotografías la representación urbana típica del flâneur, en una época de declive del sketch costumbrista, su medio tradicional de representación. Es decir, la mirada del flâneur pasa de la cultura escrita a la visual. 
Por mi parte, considero que en la segunda mitad del siglo XIX, con la promoción del periodismo ilustrado (diarios y revistas), se favoreció a nivel visual tanto la ideología del flâneur consumidor (en las revistas para la burguesía y la pequeña burguesía) como la del badaud, ávido de acontecimientos sensacionalistas (en los diarios populares).

\section{Conclusiones}

La investigación sobre el flâneur en la pintura, principalmente de la impresionista, se ha centrado en el desempeño del artista como flâneur: busca sus temas pictóricos en la calle y deja de tratar exclusivamente temas mitológicos o históricos. El artista peripatético determina, a su vez, el punto de vista de las obras pictóricas: el encuadre aleatorio, domina en las escenas urbanas de la pintura impresionista. Sus pintores callejearon por París y representaron esta actividad y su percepción correspondiente desde un punto de vista móvil.

En el ámbito de la representación pictórica del flâneur y de la flaneuse, los resultados de las investigaciones son ambivalentes. El flâneur emprende una actividad temporal y la pintura no puede registrar esta última dimensión. En estas circunstancias, los analistas han inferido la presencia del flâneur en cuadros que visualizan a un paseante que, en actitud de dandy ocioso, transita por la ciudad. El modelo iconográfico establecido por las fisiologías costumbristas de la década de 1840, fundamentado sobre todo en el código vestimentario, suele ser utilizado por los historiadores del arte para distinguirlo en los cuadros decimonónicos que representan el espacio de la calle. Por su parte, la flaneuse ha sido identificada en cuadros que tienen personajes femeninos solitarios o que transitan en pareja en calles y parques (en todo caso, sin compañía masculina).

En la historia de la fotografía, el interés se ha centrado en interpretar a los fotógrafos que representan la calle desde la mirada del flâneur. Sobre todo, se han analizado las callejuelas de las tomas melancólicas de Eugène Atget y la fotografía humanista de Robert Doisneau y Henry-Cartier Bresson. Todavía no existen análisis que identifiquen al flâneur y a la flaneuse en el discurso fotográfico.

También se ha definido el punto de vista móvil de la cámara cinematográfica como equivalente a la mirada móvil e indolente del flâneur, sobre todo por las teorías realistas del cine, que destacan la capacidad que tiene la imagen en movimiento de registrar la fugacidad de los acontecimientos urbanos. De esta mirada participan las sinfonías urbanas de los años veinte, con su mirada callejera (El hombre de la cámara, Nada más que las horas, Berlín, la sinfonía de la gran ciudad).

También se ha analizado la presencia del flâneur y de la flaneuse como personaje en las películas de ficción y en documentales. Aparecen estos personajes en pocas películas: la intencionalidad descriptiva, la indolencia y la ausencia de un objetivo definido, actitudes típicas en este tipo social, se enfrentan a la acción dinámica típica del cine narrativo. La flanerie también ha encontrado cierta revitalización en el cine postmoderno, donde se aprecian personajes desorientados en el espacio público.

\section{Notas}

1. El flâneur ha sido investigado en los últimos años en el costumbrismo español y el modernismo latinoamericano por Dorde Cuvardic García. Entre otros, podemos mencionar los siguientes artículos: "El flâneur y la flanerie en el costumbrismo español", Revista de Filología y Lingüística. 35 (1): 23-38; "La reflexión sobre el flâneur y la flanerie en los cronistas modernistas latinoamericanos". 
Kañina. 33 (19): 21-35; "La técnica del "cuadro" en el costumbrismo y el modernismo: la urbe como espectáculo, teatro y bazar”, Letras de Deusto. 39 (124): 95-113; “Tipología de espacios públicos y privados en el costumbrismo de Larra y Mesonero Romanos”, Káñina (en prensa).

2. $\quad$ Marxist Quarterly, enero 1937.

3. Del libro de Clark interesan, sobre todo, los capítulos La vista desde la Catedral de Notre-Dame, centrado en las escenas callejeras, y Un bar en el Folies-Bèrgere, dedicado a la cultura del espectáculo.

4. Nos referimos a cuadros como La calle (Berlín) (1913), Escena callejera de Berlín (1913), Cinco mujeres en la calle (1913), Potsdamer Platz (1914), Dos mujeres en la calle (1914), o Friedrichstraße, Berlín (1914).

5. Está disponible la siguiente edición facsimilar: Margaret A. Rose (Ed.). 2007. Flâneurs and Idlers. Louis Huart: Physiologie du flâneur (1841). Albert Smith: The Natural History of the Idler upon Town (1848). Bielefeld: Aisthesis Verlag.

6. Es el caso de las ilustraciones de los siguientes sketches: Nuestro vecino de al lado, Seven Dials, Las recreaciones de Londres -Los Jardines de Té-, The Last Cab-Driver, El primero de Mayo o Un carterista en custodia.

7. Como explica Körner (1996: 49-50), el individuo moderno individualizado en la multitud no es el tema de El juramento del juego de la pelota, 1791, de David, donde hay una clara separación entre la multitud y los protagonistas, claramente individualizados, del juramento; es decir, no aparecen los individuos que juramentan en una multitud; en cambio, esta entidad colectiva, aunque sin individualidades destacadas, ya aparece como tema alrededor de la década de 1830 en los trabajos de Delacroix (p.ej., Boissy d'Anglas en el convento, 1831).

8. De hecho, en La fisiología del flâneur -en los capítulos 4, 13, 14-, de Huart, aparecen ilustraciones que le representan en actitud de observar el escaparate de una tienda (en los dos primeros casos un carterista le roba la billetera, mientras que el segundo caso se encuentra acompañado de un amigo). La misma iconografía aparece en La historia natural del ocioso en la ciudad, de Albert Smith. En esta contribución inglesa, el Idler observa escaparates (en los capítulos 3 y 7, en el primer caso al lado de un personaje con apariencia de carterista).

9. En España se describe este tipo social, el ocioso apoyado en una esquina, en la escena costumbrista Paseo por las calles, de Mesonero Romanos

10. Forgione analiza cuadros como El puente de las Artes (alrededor de 1867-68), y El puente Nuevo, París (1872), de Pierre-Auguste Renoir; La iglesia de San Felipe de Roule, París (1877), o L'attente; la calle de Chateaubriand (1888), de Jean Béraud; La Plaza de la Concordia (El Vizconde Lepic y sus hijas cruzan la Plaza de la Concordia) (1875), de Edgar Degas; Muchachas caminantes, alrededor de 1891, de Édouard Vuillard; El puente de Europa (1876), y Calle de París: día de lluvia (1877), de Gustave Caillebotte; Esquina callejera (alrededor de 1897), de Pierre Bonnard; El Bulevar de los Capuchinos (1873), de Claude Monet; o La lavandera (1895), de Félix Vallotton.

11. Estoy de acuerdo con Sabine Hake, en "Girls and Crisis - The Other Side of Diversion" (1987. New German Critique. 40: 147), cuando traduce Zerstreuung al inglés como diversión, en lugar de distracción, al considerar que el último término reprime la ambivalencia del primero. En español, al igual que en inglés, diversión es conceptualmente más rico, ya que incorpora también entre su significado la distracción, la saturación, el tedio que finalmente puede provocar la diversión.

12. Con razón señala Dimendberg que estas películas han sido comprendidas en relación a los argumentos que los sociólogos Simmel, Benjamin y Kracauer han ofrecido de la modernidad urbana, donde domina este punto de vista sobre las relaciones sociales.

13. El ritmo diario de la urbe sustituye al ritmo de las estaciones, de mayor importancia en la cultura clásica. Cuvardic (2008: 33-49) ya ha analizado exhaustivamente este subgénero documental desde el tema de las horas del día. En consecuencia, el análisis de estas películas, en la presente oportunidad, no se detendrá en este tópico.

14. La idea más común es considerar que, con excepción del expresionismo, la imagen de la ciudad en el arte vanguardista es principalmente celebratoria. Así, por ejemplo, Dimendberg (1997: 63) afirma que la cultura visual urbana de las tres primeras décadas del siglo XX (Dziga Vertov, René Clair o 
Walter Ruttmann en el cine; Fernand Léger y Robert Delaunay en la pintura; László Moholy-Nagy en fotografía) ofrecen himnos dinámicos al progreso industrial y las fuerzas productivas urbanas; desde la estética del shock y de la fragmentación, que busca escapar de la anomia urbana y que yuxtapone y convierte los elementos de la cultura urbana en formas abstractas.

15. Documental metalingüístico y de observación son categorías que proceden de la propuesta tipológica de Bill Nichols (1997. La representación de la realidad. Cuestiones y conceptos sobre el documental. Barcelona: Editorial Paidós).

16. La visión baudelariana ofrecida es la visión crítica de Los pequeños poemas en prosa y Las flores del mal, no del elogio de la modernidad de El pintor de la vida moderna.

17. Cuando veamos posteriormente a diversos sujetos burgueses que la cámara destacará desde la deformación caricaturesca, el espectador recuperará los encuadres de los gigantes y los interpretará como representaciones alegóricas de los burgueses ociosos que durante el día ocupan el paseo marítimo.

18. Este procedimiento metacinematográfico se emplea constantemente, y no sólo al inicio, en El hombre de la cámara.

19. Caracterizados por la alta abstracción de la línea férrea, los planos del tren en marcha, que termina por detenerse ante el puente para dejar paso a los barcos, nos recuerdan el inicio de Berlín..., con la llegada del tren a la capital alemana, mientras que la activación de los engranajes del puente recuerda todos aquellos planos de Berlín... y de El hombre de la cámara dedicados a la activación y uso de las máquinas de las fábricas.

\section{Bibliografía}

Addison, Joseph. 1991. Los placeres de la imaginación y otros ensayos de The Spectator. Madrid: Visor.

Baudelaire, Charles. 1996. Salones y otros escritos sobre arte. Madrid: Visor.

Brand, Dana. 1991. The spectator and the city in the nineteenth-century American literature. Cambridge: Cambridge University Press.

Bruno, Giuliana. 1997. "Site-seeing: Arquitecture and the Moving Image". Wide Angle. 19 (4): $8-24$.

Chang, Ting. 2006. "Disorienting Orient: Duret and Guimet, anxious flâneurs ins Asia". En: D’Souza y McDonough (Eds.), 65-78.

Chapman, Jay. 1979. “Two Aspects of the City: Cavalcanti and Ruttmann”. Documentary Tradition (2 ${ }^{\text {nd }}$ Ed.). New York: W.W. Norton and Company.

Clark, Timothy J. 1984. The painting of modern life: Paris in the Art of Manet and his followers. Princeton: Princeton University Press.

Cuvardic García, Dorde. 2008. "El tema de las horas del día desde el costumbrismo hasta el cine vanguardista de las sinfonías urbanas". Revista de Filología y Lingüística. 34 (2): 33-49. 2009a. "El flâneur y la flanerie en el costumbrismo español”. Revista de Filología y Lingüística. 35 (1): 23-38.

2009b. "La reflexión sobre el flâneur y la flanerie en los cronistas modernistas latinoamericanos". Kañina. 33 (19): 21-35.

2009c. "La técnica del "cuadro" en el costumbrismo y el modernismo: la urbe como espectáculo, teatro y bazar”. Letras de Deusto. 39 (124): 95-113.

2011. “Tipología de espacios públicos y privados en el costumbrismo de Larra y Mesonero Romanos”. Káñina. 35 (1): 67-80. 
Czaplika, John V. 1991. "Pictures of a city at work, Berlin, circa 1890-1930: visual reflections on social structures and technology in the modern urban construct". En: Haxthausen, 3-36.

Dickens, Charles. 1957. Sketches by Boz. Illustrative of every-day life and every-day people. London: Oxford University Press.

Diethe, Carol. 2000. "Anxious Spaces in German Expressionist Films”. En: Konstantarakos (Ed.), 52-63.

Dimendberg, Edward. 1997. "From Berlin to Bunker Hill: Urban Space, late Modernity, and Film Noir in Fritz Lang's and Joseph Losey's M". Wide Angle. 19 (4): 62-93.

Donald, James. 1999. Imagining the modern city. London: The Athlone Press.

D’Souza, Aruna. 2006. "Why the Impresionists never painted the department store?". En: D’Souza y McDonough (Eds.), 129-147.

D’Souza, Aruna y Tom McDonough (Eds.). 2006. The invisible flâneuse? Gender, public space, and visual cultura in nineteenth-century Paris. Manchester: Manchester University Press.

Faulstich, Werner y Helmut Korte. (Comps.). 1995. Cien años de cine. 1925-1944. El cine como fuerza social. Vol 2. Madrid: Siglo Veintiuno.

Fisher, Jaimey. 2005. "Wandering in/to the Rubble-Film: Filmic Flânerie and the Exploded Panorama after 1945". The German Quarterly. 78 (4): 461-480.

Friedberg, Anne. 1993. Window shopping. Cinema and the postmodern. Berkeley: University of California Press.

Fritzsche, Peter. 1996. Reading Berlin 1900. Cambridge, Massachusetts: Harvard University Press.

Forgacs, David. 2000. “Antonioni: Space, Place, Sexuality”. En: Konstantarakos (Ed.), 101-111.

Forgione, Nancy. 2005. "Everyday Life in Motion: The Art of Walking in Late-NineteenthCentury Paris". The Art Bulletin. 87 (4): 664-687.

Fournel, Victor. 1857. Ce qu'on voit dans les rues de Paris. Paris: Dentu.

Gomolla, Stephanie. 2009. Distanz und Nähe. Der Flâneur in der französischen Literatur zwischen Moderne und Postmoderne. Würzburg: Königshausen und Neumann.

Gretton, Tom. 2006. "Not the flâneur again: reading magazines and living the metropolis around 1880". En: D’Souza y McDonough (Eds.), 94-112.

Gunning, Tom. 1997. "From the Kaleidoscope to the X-Ray: Urban Spectatorship, Poe, Benjamin, and Traffic in Souls (1913)". Wide Angle. 19 (4): 25-61.

Hake, Sabine. 1994. "Urban Spectacle in Walter Ruttmann's Berlin, Symphony of the Big City”. En: Kniesche y Brockmann (Eds), 127-142.

1987. “Girls and Crisis -The Other Side of Diversion”. New German Critique. (40): 147-164.

Hamm-Ehsani, Karin. 2004. "Screening Modern Berlin: Lola Runs to the Beat of a New Urban Symphony”. Seminar. 40 (1): 50-65.

Haxthausen, Charles. 1991a. “'A New Beauty’: Ernst Ludwig Kirchner's Images of Berlin”. En: Berlin. Culture and metropolis. Minneapolis: University of Minnesota Press. 1991b. Berlin. Culture and metropolis. Minneapolis: University of Minnesota Press.

Hegel, Friederike von. 2007. "Angela Schanelecs 'Marseille' als Flâneurfilm”. München: GRIN Verlag GmbH.

Herbert, Robert. 1988. Impressionism: art, leisure, and Parisian society. New Haven: Yale University Press. 
Huyssen, Andreas y David Bathrick (Eds.). 1989. Modernity and the Text: Revisions of German Modernism. New York: Columbia University Press.

Iskin, Ruth E. 2003. "The Pan-European Flâneuse in Fin-de Siècle Posters: Advertising Modern Women in the City". Nineteenth-Century Contexts. 25 (4): 333-356.

2006. "The flâneuse in French fin-de-siècle posters: advertising images of modern women in Paris". En: D’Souza y McDonough, 113-128.

Jesinghausen, Martin. 2000. “The Sky over Berlin as Transcendental Space: Wenders, Döblin and the "Angel of History"'. En: Konstantarakos (Ed.), 77-92.

Kniesche, Thomas y Stephen Brockmann (Eds). 1994. Dancing on the Volcano. Essays on the Culture of the Weimar Republic. Columbia: Camden House.

Konstantarakos, Myrto (Ed.). 2000. Spaces in European Cinema. Exeter: Intellect Books.

Korte, Helmut. 1995. "El mundo como corte transversal: Berlin. Die Sinfonie der Grossstadt [Berlín, sinfonía de una gran ciudad]”. Faulstich y Korte (Comps.), 90-109.

Kracauer, Siegfried. 1996. Teoría del cine. La redención de la realidad física. Barcelona: Paidós.

Körner, Hans. 1996. Edouard Manet. Dandy, Flâneur, Maler. München: Fink.

Lewis, Beth Irwin. 1991. "Lustmord: inside the windows of the metropolis". En: Haxthausen (Ed.), 111-140.

Macey, David. 2000. The Penguin Dictionary Critical Theory. London: Penguin.

Mesonero Romanos, Ramón de. 1967. "Paseo por las calles". En: Escenas matritentes. Barcelona: Bruguera.

Minden, Michael. 1985. "The city in early cinema: Metropolis, Berlin and October". En: Timms y Kelley (Eds.), 193-213.

Monsiváis, Carlos. 1995. Los rituales del caos. México D.F.: Era.

Murphy, Amy. 2006. "Traces of the Flâneuse. From Roman Holiday to Lost in Translation". Journal of Arquitectural Education. 60 (1): 33-42.

Myriam, Juan. 2004. "Le cinéma documentaire dans la rue parissienne". Sociétés et Représentations. (17): 291-314.

Nichols, Bill. 1997. La representación de la realidad. Cuestiones y conceptos sobre el documental. Barcelona: Editorial Paidós.

Penz, François and Maureen Thomas (Eds.). 1997. Cinema and arquitecture. London: British Film Institute.

Pollock, Griselda. 1988. Vision and difference. Femininity, feminism and histories of art. London: Routledge.

Poppe, Nicolas. 2009. "Siteseeing Buenos Aires in the early Argentine sound film Los tres berretines". Journal of Cultural Geography. 26 (1): 49-69.

Reff, Theodore. 1988. "Manet and the Paris of Haussmann and Baudelaire". En: Sharpe y Wallock (Eds.), 135-167.

Rifkin, Adrian. 1993. Street noises: Parisian Pleasure, 1900-40. Manchester: Manchester University Press.

Rose, Margaret A. (Ed.). 2007. "Introduction”. Flâneurs and Idlers. Louis Huart: Physiologie du flâneur (1841). Albert Smith: The Natural History of the Idler upon Town (1848). Bielefeld: Aisthesis Verlag. 
Sasselin, Rémi G. 1990. Le Bourgeois et le bibelot. Paris: Ed. Albin Miche.

Scherpe, Klaus R. 1989. "The city as narrator: the modern text in Alfred Döblin's Berlin Alexanderplatz". En: Huyssen y Bathrick (Eds.), 162-177.

Sharpe, William y Leonard Wallock (Eds.). 1988. Visions of the modern city. Essays in history, art, and literature. Baltimore: The John Hopkins University Press.

Shaya, Gregory. 2004. "The Flâneur, the Badaud, and the Making of a Mass Public in France, circa 1860-1910”. American Historical Review. 109 (1): 41-77.

Shohat, Ella y Robert Stamm. 2000. Multiculturalismo, cine y medios de comunicación. Barcelona: Paidós.

Sontag, Susan. 2007. Sobre la fotografía. Buenos Aires: Alfaguara.

Stierle, Karlheinz. 1980. "Baudelaire and the tradition of the Tableau de Paris". New Literary History. 11 (2): 345-361.

Thomas, Greg M. 2006. "Women in public: the display of feminity in the parks of Paris". En: D’Souza y McDonough, 32-48.

Timms, Edward y David Kelley (Eds.). 1985. Unreal city. Manchester: Manchester University Press.

Villanueva, Darío. 2008. Imágenes de la ciudad. Poesía y cine, de Whitman a Lorca. Valladolid: Cátedra Miguel Delibes.

Walkowitz, Judith R. 1995. La ciudad de las pasiones terrible. Narraciones sobre el peligro sexual en el Londres victoriano. 1992. Madrid: Cátedra.

Walser, Robert. 2001. El paseo. Madrid: Siruela.

Ward, Simon. 2007. "The Memory of Images or Images of Memory? Thomas Schadt's Berlin. Sinfonie einer Großstadt, Contemporary Visual Culture and the Remembrance of Berlin Past”. En: Weiss-Sussex y Zitzlsperger (Eds.), 155-167.

Wechsler, Judith. 1982. A Human Comedy: Physiognomy and caricature in $19^{\text {th }}$ century Paris (Foreword by Richard Sennet). London: Thames and Hudson.

Weihsmann, Helmut. 1997. 'The City in Twilight. Charting the Genre of the 'City Film' 19901930”. En: Penz y Thomas (Eds.), 8-27.

Weiss-Sussex, Godela y Ulrike Zitzlsperger (Eds.). 2007. Berlin. Kultur und Metropole in den zwanziger und seit den neunziger Jahren. Munich: Iudicium.

\section{Filmografía}

Vigo, Jean. 1930. A propósito de Niza (À propos de Nice). Madrid: Sherlock films, B/N. 23 min.

Siodmak, Robert y Edgar G. Ulmer. 1929/30. Individuos en Domingo (Menschen am Sonntag). Alemania: Studio 29, Moriz Seeler, Präsens films, B/N. 73 min.

Cavalcanti, Alberto. 1926. Nada más que las horas (Rien que les heures). Berlín: Kino International, B/N. 46 min.

Walther Ruttmann. 1965. Berlín, la sinfonía de la gran ciudad (Berlin, die Sinfonie der Großstadt). Alemania: Bundesarchiv Berlin. ZDF/ARTE Mainz, B/N. 65 min.

Vertov, Dziga. 1929. El hombre de la cámara (Человек с киноаппаратом). Alemania: Arte Edition B/N. 67 min. 


\section{Pintura}

Béraud, Jean. 1878-1882. Paris, on the boulevard. Recuperado de: http://www.aloj.us.es/ galba2/BERAUD/Beraud_BvCapucines1.htm Consulta: 10 de abril del 2013.

Caillebote, Gustave. 1876. Le pont de l'Europe. Recuperado de: http://www.npr. org/2011/06/03/136592986/gustave-caillebotte-impressions-of-a-changing-paris. Consulta: 11 de marzo del 2013.

Cruikshank, George. 1837-1839. Streets Morning. Recuperado de: http://web.missouri. edu/ westn/images/8250/450px/sketches_by_boz/cruikshank_streets_morning.jpg Consulta: 11 de marzo del 2013.

Degas, Edgar. 1867-1868. James Tissot. Recuperado de: http://www.ncartco.com/productp/126288.htm Consulta: 11 de marzo del 2013.

Degas, Edgar. 1875. Place de la Concorde. Recuperado de: http://www.19thcenturyartfacos.com/artwork/viscount-lepic-and-his-daughters-crossing-place-de-la-concorde Consulta: 11 de marzo del 2013.

Parry, James Orlando. 1835. A London Street Scene. Recuperado de: http://thehoarding.wordpress.com/about/ Consulta: 27 de enero del 2011. 